\title{
The Effect of Bentonite on the Survival of Azotobacter chroococcum in Sandy Soil in a Long-Term Plot Experiment
}

\author{
Janusz Czaban*, Barbara Wróblewska \\ Agricultural Microbiology Department, Institute of Soil and Plant Cultivation - State Research Institute, \\ 8 Czartoryskich St. 24-100 Puławy, Poland
}

Received: 29 June 2016

Accepted: 18 August 2016

\begin{abstract}
In a 38-year microplot experiment, very poor sandy soil deprived of the humus layer was amended with waste bentonite (BNT) in four doses of $0,30,60$, and $120 \mathrm{t} \mathrm{ha}^{-1}$ in order to improve the properties of the soil. During the first 30 years, the soils were fertilized with organic and mineral fertilizers and planted with various crops, while during the next eight years they were exposed to bare fallowing without fertilization. At the beginning of the experiment, the soils were inoculated with Azotobacter chroococcum. During the next 12 consecutive years we observed a gradual decrease of colony forming units (CFU) of these bacteria. The decrease of the CFU numbers of $A$. chroococcum was the fastest in the control soil (after 10 years A. chroococcum was not found in this soil). BNT significantly slowed down this decrease (1.7-3.3-times), and the effect was dose-dependent. The CFU numbers were strongly positively correlated with soil $\mathrm{pH}$. After 7/8-year fallowing, when $\mathrm{pH}$ of the soils drastically decreased (especially in the $5-30 \mathrm{~cm}$ layer), A. chroococcum was found only in a 30-55 cm layer in the soil with $120 \mathrm{tha}^{-1} \mathrm{BNT}$, where soil $\mathrm{pH}\left(\mathrm{H}_{2} \mathrm{O}\right)$ was above 6. In a four-year field experiment with another sandy soil, BNT addition increased the CFU number of native Azotobacter spp. (30, 80, and 900-times for 30, 60, and $120 \mathrm{tha}^{-1}$ of BNT, respectively).
\end{abstract}

Keywords: sandy soil improvement, Azotobacter chroococcum, bentonite, carbonates, soil pH

\section{Introduction}

Due to the low content of clay, sandy soils are infertile because they usually contain little humus, nutrients, and water. Moreover, many of these soils became acidified because of their low buffering capacity [1-5].

Bentonite, a rock predominantly consisting of the clay mineral montmorillonite, has been recognized in different parts of the world as a very good material for the

*e-mail: czaban@iung.pulawy.pl improvement of such infertile, coarse-textured soils [6-9]. Czaban and Siebielec [10] as well as Czaban et al. [1112] presented data of a long-term (38 years) microplot experiment on the improvement of the physical and chemical properties of a very poor and infertile sandy soil by the addition of waste bentonite containing carbonates. They found that this bentonite (BNT) in the upper $30 \mathrm{~cm}$ soil layer significantly increased $\mathrm{pH}$, cation exchange capacity, contents of water, clay, silt, sand fraction with particle diameter $<0.1 \mathrm{~mm}$, organic $\mathrm{C}$ (especially the humin fraction), total $\mathrm{N}, \mathrm{Ca}, \mathrm{Mg}, \mathrm{Zn}$, and $\mathrm{Mn}$, as well as available $\mathrm{P}$ and $\mathrm{K}$. 
Another aim of this long-term experiment was to check how BNT addition to the soil affected its microbiological and biochemical properties. This paper presents the first part of the data of these studies. It concerns the influence of BNT on the survival of Azotobacter chroococcum bacteria introduced to the soils.

Bacteria belonging to the genus Azotobacter are freeliving, aerobic diazotrophs commonly occurring in soil. $A$. chroococcum is the most prevalent species [13-16]. The presence of Azotobacter sp. in soils often has beneficial effects on plants $[15,17-25]$. In soils, populations of Azotobacter spp. are affected by soil physico-chemical properties, (e.g., organic matter and water content) and they are especially sensitive to low $\mathrm{pH}$ [13-14, 22, 26-27].

\section{Materials and Methods}

\section{Experimental Design and History of the Microplots}

Our microplot experiment was established in 1973 at the Institute of Soil Science and Plant Cultivation in Puławy in eastern Poland (51 $\left.24^{\prime} \mathrm{N}, 21^{\circ} 57^{\prime} \mathrm{E}\right)$, on a subsoil (after removing the humus layer to $25 \mathrm{~cm}$ depth because of a study on the effect of BNT on the formation of humus) of an acidic sandy soil ( $\mathrm{pH} \mathrm{H}_{2} \mathrm{O}$ 5.4) containing $4 \%$ particles $<0.02 \mathrm{~mm}$ and $3.5 \mathrm{~g} \mathrm{~kg}^{-1}$ of organic carbon in the humus layer. In what follows, this exposed subsoil will be called 'the basic soil.' It contained 95\% sand, 4\% silt, and $1 \%$ clay and at the beginning of the experiment, and only traces of organic C. The upper $(0-30 \mathrm{~cm})$ layer of the basic soil was enriched with BNT at rates of $0,30,60$, and $120 \mathrm{t} \mathrm{ha}^{-1}$. The BNT contained $1.66 \%$ of total potassium (and $0.39 \%$ of $\mathrm{K}$ soluble in $10 \% \mathrm{HCl}), 0.73 \%(0.60 \%)$ sodium, $4.95 \%(4.26 \%)$ of calcium and $1.22 \%(0.60 \%)$ of magnesium. Its cation exchange capacity was equal to $26 \mathrm{cmol} \mathrm{kg}^{-1}$. The microplot experiment involved 16 plots $\left(0.8 \mathrm{~m}^{2}\right)$ with concrete walls ( $1 \mathrm{~m}$ diameter, $1 \mathrm{~m}$ depth), and four replicates for each treatment [11-12]. As the bacteria of the genus Azotobacter were absent in the basic soil and BNT, in 1973 (two months after BNT addition to the soil) the soils were inoculated with Azotobacter chroococcum strain 34B from the collection of the Microbiology Department of the Institute of Soil Science and Plant Cultivation in Puławy.

In the first two years of the experiment, the microplots were planted with white mustard and lupine in order to enrich the soil with green manure. Subsequently (for 28 years until 2002), the microplots were planted with potatoes, various cereals (oat, rye, triticale, barley, wheat), alfalfa, and sometimes with white mustard as the second crop. During these 30 years, the soils were treated with mineral fertilizers and exogenous organic matter. Before growing potatoes, the soils were fertilized with farmyard manure, and after growing cereals they were enriched with residual straw, and after growing mustard, alfalfa, or lupine with the corresponding green manure. The $\mathrm{pH}$ of the control soil which was not enriched with BNT had to be regulated by a $\mathrm{CaCO}_{3}$ addition approximately every four years. Since 2003 the plots were left as bare fallow with no fertilization to find out how stable the organic and mineral soil constituents would be [11-12].

During the period of 1973-1985 and additionally in 1990, the soil samples were taken from the 0-30 cm layer. After the period of fallowing, in 2009 and 2010 all plots were sampled from soil depths of 5-30 and $30-55 \mathrm{~cm}$; in 2009 from all the treatments, whereas in 2010 it was only from the control soil and the soil with the highest dose of BNT. In 2009 and 2010 the uppermost layer $(0-5 \mathrm{~cm})$ of the soils was removed because of intensive but irregular growth of algae on the surface, which would falsify the concentrations of soil $\mathrm{C}$ and $\mathrm{N}$ as determined in the same samples. The samples were placed in sterile containers for transport to the laboratory. At the laboratory, the samples were immediately microbiologically analyzed after being sieved through $2 \mathrm{~mm}$. The soils from the microplots were not examined in 1986-89 and 1991-2008.

\section{Experimental Design of the Field Experiment}

The field experiment (without replications) was conducted in 1973-1976 at the Experimental Station in Sadłowice, a village near Puławy $\left(51^{\circ} 23^{\prime} \mathrm{N}, 21^{\circ} 57^{\prime} \mathrm{E}\right)$ on $20 \mathrm{~m}^{2}$ fields containing sandy acidic soil (90\% sand, 7\% silt, and $3 \%$ clay; $\mathrm{pH} \mathrm{H}_{2} \mathrm{O} 5.5 ; 7.7 \mathrm{~g} \mathrm{~kg}^{-1}$ of organic $\mathrm{C}$; and $0.75 \mathrm{~g} \mathrm{~kg}^{-1}$ of total $\mathrm{N}$ ). Before the experiment, this soil was fertilized with $\mathrm{CaCO}_{3}$ in 1966 and in 1972, and with farmyard manure in 1967. In 1973 the upper $30 \mathrm{~cm}$ layer of this soil was amended with the same bentonite (BNT) and the same amounts as in the microplot experiment. In this way, this field experiment consisted of four treatments with various amounts of bentonite $(0,30,60$, and $120 \mathrm{t} \mathrm{ha}^{-1}$ ). In 1973 the fields were seeded with barley, in 1974 with potato, in 1975 with lupine, and in 1976 with oat. The fields under cereals were fertilized with nitrogen, phosphorus, and potassium mineral fertilizers. Potatoes were fertilized with both farmyard manure and mineral fertilizers, and lupine only with mineral $\mathrm{P}$ and $\mathrm{K}$ fertilizers.

The soils of the fields were not inoculated with A. chroococcum as the soils in the microplots. Only populations of the native bacteria belonging to the genus Azotobacter were studied in the soils. As all the colonies of these bacteria turned dark brown after 5-7 days of incubation (similarly as the bacteria in the microplot experiment), it was concluded that they also belonged to A. chroococcum species [14].

\section{Preparation of the Bacterial Inoculum}

Azotobacter chroococcum strain 34B was grown in a liquid Burk's N-free medium [28] in 250-ml Erlenmeyer flasks on a shaker platform rotating at $100 \mathrm{rpm}(100 \mathrm{ml}$ per flask). Cultures of the bacteria in the late log-phase of growth from all flasks were mixed together. The mixture containing approximately $1 \times 10^{9} \mathrm{CFU} \mathrm{ml}^{-1}$ after 10 -fold dilution with tap water was used as an inoculum (100 $\mathrm{ml}$ into the soil of each plot to give the final count 
of approximately $10 \times 10^{9} \mathrm{CFU}$ per plot). The control soil obtained the same amount of the inoculum killed by autoclaving. The soils were carefully mixed with a $30 \mathrm{~cm}$ spade after inoculation.

\section{Determination of Soil $\mathrm{pH}$ and the Number of A. chroococcum}

Soil $\mathrm{pH}$ was measured with a glass electrode in a slurry of $10 \mathrm{~g}$ of soil and $25 \mathrm{~cm}^{3}$ of deionized water.

Numbers of colony forming units (CFU) of $A$. chroococcum were determined by dilution platecount method on Fenglerova's N-free agar medium [14] containing: $\mathrm{K}_{2} \mathrm{HPO}_{4} 0.5 \mathrm{~g}, \mathrm{MgSO}_{4} 0.2 \mathrm{~g}, \mathrm{NaCl}$ $0.2 \mathrm{~g}, \mathrm{CaCO}_{3} 5 \mathrm{~g}$, sucrose $10 \mathrm{~g}$, agar $12 \mathrm{~g}$, and $\mathrm{H}_{2} \mathrm{O}$ dist. $1,000 \mathrm{~mL}$ and traces of $\mathrm{Mn}, \mathrm{Fe}$, and Mo after 48-72 hours of incubation at $28^{\circ} \mathrm{C}$.

For the 1973-1985 period, the year means (of 4-6 measurements per year) of the soil $\mathrm{pH}$ and Azotobacter CFU values are presented.

\section{Statistical Analysis}

In the case of the microplot experiment, the regression equations were calculated on the basis of the values from the first 12 consecutive years (until 1985) in order to: 1) compare the changes of both the CFU numbers of A. chroococcum and the soil $\mathrm{pH}$ between the soils with various doses of BNT and 2) determine the relationships of the CFU numbers of $A$. chroococcum on the soil $\mathrm{pH}$ in the individual treatments.

In the case of the field experiment, the coefficients of linear Pearson correlation between the CFU numbers of Azotobacter spp., soil pH, and BNT doses were determined.

\section{Results}

\section{Microplot Experiment}

Immediately after inoculation in 1973, the CFU numbers of $A$. chroococcum amounted from $23 \times 10^{3} \mathrm{~g}^{-1}$ in the control soil to $20 \times 10^{3}, 19 \times 10^{3}$, and $16 \times 10^{3}$ in $1 \mathrm{~g}$ of the soils with 30,60 , and $120 \mathrm{t} \mathrm{BNT} \mathrm{ha}^{-1}$. In the next year, the CFU numbers of $A$. chroococcum increased 2-5-times in the soils enriched with BNT, whereas in the control soil the CFU number of Azotobacter decreased five times. During the next 11 consecutive years (until 1985), the decreases of the numbers of these bacterial CFUs were observed in the case of all the treatments (Fig. 1). When the CFU numbers of $A$. chroococcum were transformed to logarithms to base 10, the changes of these bacterial CFUs can be described with the following linear equations:

- $\quad$ For $0 \mathrm{t} \mathrm{ha}^{-1}: y=-0.442 x+3.88, R^{2}=0.94$

- For $30 \mathrm{t} \mathrm{ha}^{-1}: y=-0.303 x+4.45, R^{2}=0.95$

- For $60 \mathrm{t} \mathrm{ha}^{-1}: y=-0.187 x+4.45, R^{2}=0.90$

- For $120 \mathrm{tha}^{-1}: y=-0.151 x+4.49, R^{2}=0.87$

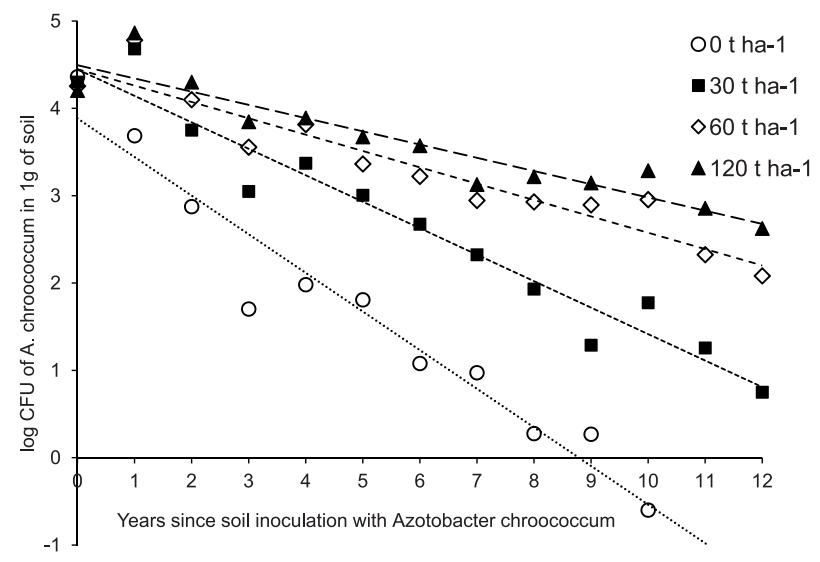

Fig. 1. Effect of the soil amendment with BNT $(0,30,60$ and $120 \mathrm{t} \mathrm{ha}^{-1}$ ) on the CFU numbers of Azotobacter chroococcum during 12 consecutive years since the soils inoculation with these bacteria.

...where $y$ is $\log$ of CFU numbers of A. chroococcum and $x$ is time in years since the year of soil inoculation.

The values of slopes are becoming gradually less negative with the increase of BNT dose. This indicates that the decrease of the CFU numbers of $A$. chroococcum was the fastest in the control soil (as early as $1983 \mathrm{~A}$. chroococcum was not found in this soil), and higher doses of BNT slowed down this decrease more strongly. Calculations made on the basis of the above linear equations show that the logarithms of CFU numbers of $A$. chroococcum should reach value "0" (CFU number $=1$ ) after $9,15,24$, and 30 years for $0,30,60$, and $120 \mathrm{tha}^{-1}$ of BNT, respectively. This means that the amendment of the soil with 30,60 , and $120 \mathrm{tha}^{-1}$ of BNT slowed down the decrease of the number of these bacteria by approximately 1.7, 2.7, and 3.3 times.

In 1990, after 17 years of soil inoculation, $A$. chroococcum was still in BNT soils in measurable amounts of 8, 44, and 515 in $1 \mathrm{~g}$ of the dry soils for 30,60 , and $120 \mathrm{tha}^{-1}$ of BNT, respectively, and these values were on a similar level as five years earlier (in 1985) at 6, 121, and 422 per $1 \mathrm{~g}$ of the soils (Fig. 1).

Czaban and Siebielec [10] presented average year values of the $\mathrm{pH}$ of the soils of this microplot experiment during 1973-1985 and in 1990. During 1973-1985, pH of the BNT soils decreased from 8.3-8.9 in 1973 to 6.3-7.0 in 1985 with a few temporary increases (e.g., after fertilizing the soils with farmyard manure), whereas $\mathrm{pH}$ of the control soil was maintained during the period at approximately 6.5 by occasional $\mathrm{CaCO}_{3}$ fertilization (Czaban and Siebielec, 2013). In the control soil, both in 1973 and 1985, pH was at the same level of 6.3. During 1975-1984 it ranged from 6.8 in 1976 and 1979 to 6.0 in 1981. Only in 1974 was the $\mathrm{pH}$ of the control soil below 6 (5.8). In 1990 the soil $\mathrm{pH}$ values were as follows: $6.5,6.6,6.8$, and 7.1 in the soils with $0,30,60$, and $120 \mathrm{tha}^{-1}$ of BNT, respectively (Czaban and Siebielec, 2013).

The decreases of $\mathrm{pH}$ values in all BNT soils are described by the following linear equations: 


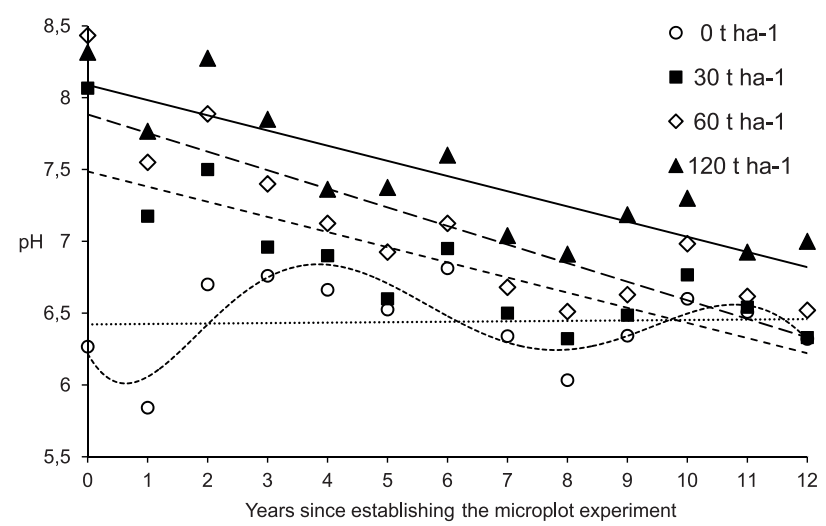

Fig. 2. Effect of the soil amendment with $\operatorname{BNT}(0,30,60$ and $120 \mathrm{t} \mathrm{ha}^{-1}$ ) on the soil $\mathrm{pH}$ during 12 consecutive years since the establishing the microplot experiment.

- $\quad$ For $30 \mathrm{t} \mathrm{ha}^{-1}: y=-0.106 x+7.49, R^{2}=0.67$

- For $60 \mathrm{t} \mathrm{ha}^{-1}: y=-0.129 x+7.88, R^{2}=0.75$

- $\quad$ For $120 \mathrm{tha}^{-1}: y=-0.106 x+8.09, R^{2}=0.74$ ...where $y$ is the soil $\mathrm{pH} \mathrm{H}_{2} \mathrm{O}$, and $x$ is time in years from the year of the experiment's establishment. The slopes of all the trend lines are very similar and they are even identical for 30 and $120 \mathrm{t} \mathrm{ha}^{-1}$, but these lines run in different ranges of $\mathrm{pH}$ : 7.5-6.2, 7.9-6.3, and 8.1-6.8 for 30, 60, and $120 \mathrm{t} \mathrm{ha}^{-1}$ of BNT, respectively (Fig. 2).

The $\mathrm{pH}$ values of the control soil do not follow the same pattern. The linear line of trend is almost parallel
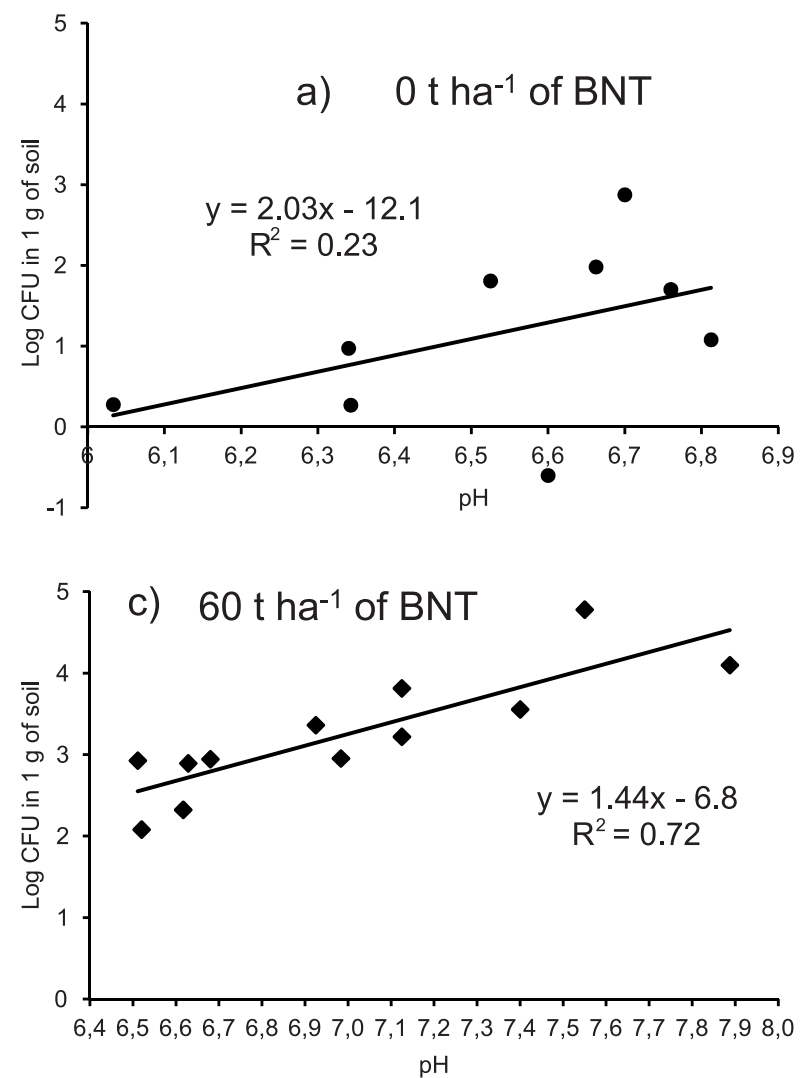

to the $x$ axis: $y=-0.003 x+0.366$ but $R^{2}$ equals merely 0.002 . Only the polynomial equation of at least degree 5 : $\mathrm{y}=-0.0004 \mathrm{x} 5+0.012 \mathrm{x} 4-0.123 \mathrm{x} 3+0.469 \mathrm{x} 2-0.427 \mathrm{x}$ +6.19 fits well $\left(R^{2}=0.61\right)$, with maxima after four and 11 years and minima after one and eight years. This polynomial trend line of $\mathrm{pH}$ of the control soil ranges from 6.8 to 6.0 (Fig. 2).

The number of $A$. chroococcum in soil enriched with BNT was significantly positively correlated with soil $\mathrm{pH}$ at $P<0.01$. When the values of the bacterial CFU numbers during 1974-85 were transformed to logarithms to base 10 , the relationships between soil $\mathrm{pH}$ and the numbers of $A$. chroococcum were linear (Fig. 3b-3d), and $R^{2}$ values for the dependence of CFU numbers of A. chroococcum on $\mathrm{pH}$ were approximately 0.7 for all BNT treatments $(n=12)$. Only in the case of the control soil was the correlation of the bacterial number with $\mathrm{pH}$ statistically insignificant, although a similar trend was observed after excluding the data from 1974 (when $\mathrm{pH}$ was the lowest $<5.8>$, but the CFU number was still relatively high $<4860 \mathrm{~g}^{-1}>$ ), but $R^{2}$ for this linear relationship between these variables equals only 0.23 (Fig. 3a). At the same $\mathrm{pH}$, the $A$. chroococcum numbers in the BNT soils calculated from the appropriate above linear equations were approximately 10-20-times higher than that in the control soil, e.g., at $\mathrm{pH} 6.6$ : $125-500 \mathrm{CFU} \mathrm{g}^{-1}$ versus $20 \mathrm{CFU} \mathrm{g}^{-1}$, at $\mathrm{pH}$ 6.8: $410-980 \mathrm{CFU} \mathrm{g}^{-1}$ versus $50 \mathrm{CFU} \mathrm{g}^{-1}$; or at $\mathrm{pH}$ 7.0: 1370-1920 $\mathrm{CFU} \mathrm{g}^{-1}$ versus $125 \mathrm{CFU} \mathrm{g}^{-1}$.
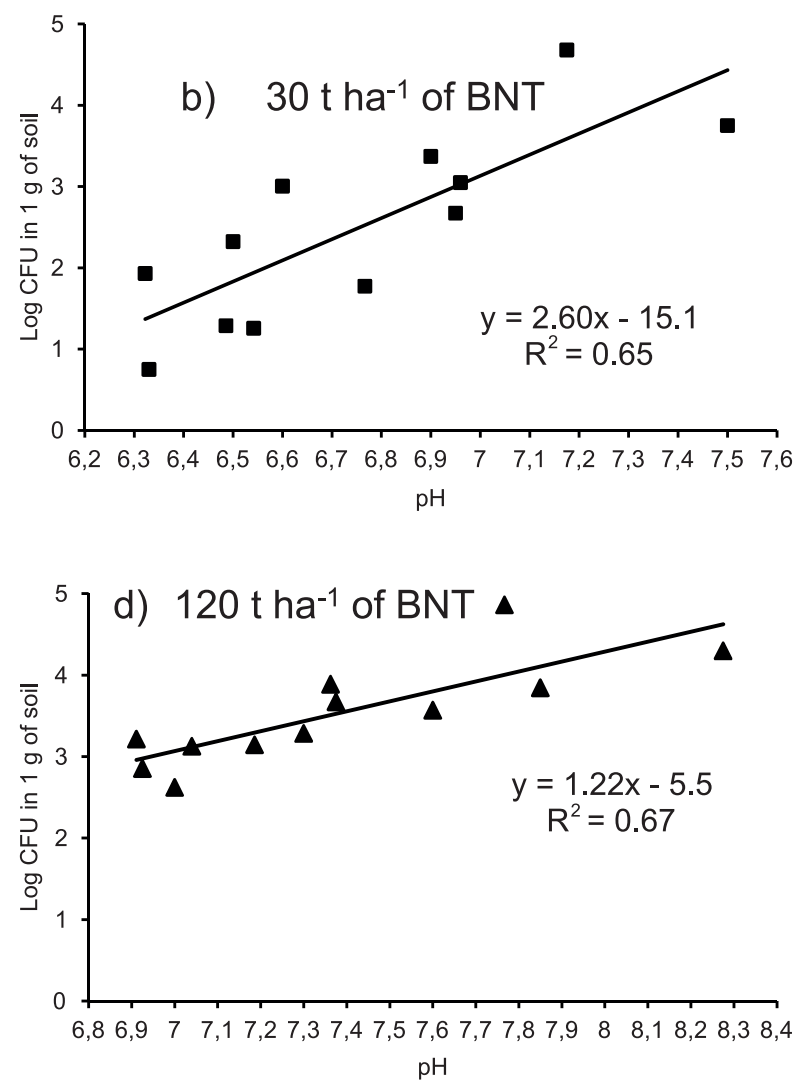

Fig. 3. Relationships between the $\log 10$ of $\mathrm{CFU}$ number of Azotobacter chroococcum and the soil $\mathrm{pH}$ in the soils with various rates of BNT (A - 0 tha-1, B - 30 tha-1, C - 60 t ha-1 and D - 120 tha-1). 
The means of the numbers of CFUs of $A$. chroococcum (90, 1,000, 2,766, and 4,608 per $1 \mathrm{~g}$ of the soils with 0 , 30,60 , and $120 \mathrm{t} \mathrm{ha}^{-1}$ of BNT, respectively) obtained after averaging the 11-year values in the period 1975-85, were strongly correlated with the BNT doses $(0,30,60$, and $\left.120 \mathrm{t} \mathrm{ha}^{-1}\right):(r=0.991$ at $P=0.01)$. The 1974 data were excluded from these calculations because the differences in the CFU numbers of $A$. chroococcum between the soils with various BNT doses did not much differ from each other $(48,000,60,000$, and 73,000 for 30,60 , and $120 \mathrm{t}$ ha $^{-1}$ of BNT, respectively, versus to $4,860 \mathrm{CFU}$ of $A$. chroococcum in the control soil). Only since 1975, after two years from soil inoculation with A. chroococcum, were more distinct differences of the CFU numbers of these bacteria proportional to the BNT doses we observed (Fig. 1).

In 2009 and 2010, after 7/8 years of fallowing, $\mathrm{pH}$ of the $5-30 \mathrm{~cm}$ soil layers significantly decreased in 2009 to 4.7, 4.9, 5.0, and 5.6 for $0,30,60$, and $120 \mathrm{tha}^{-1}$ of BNT, respectively, and in 2010 to 4.3 and 4.8 for 0 and $120 \mathrm{t} \mathrm{ha}^{-1}$ of BNT, respectively. In deeper 30-55 cm soil layers $\mathrm{pH}$ was higher. In 2009 it amounted to, respectively, 5.4, 5.6, 5.7, and 6.5 for $0,30,60$, and $120 \mathrm{tha}^{-1}$ of BNT, while in 2010, respectively: 5.0 and 6.3 for 0 and $120 \mathrm{t} \mathrm{ha}^{-1}$ of BNT. A. chroococcum was found $\left(2.5\right.$ and $\left.20 \mathrm{CFU} \mathrm{g}^{-1}\right)$ only in the lower $(30-55 \mathrm{~cm})$ layer of the soil with the highest dose of BNT, where the soil $\mathrm{pH}$ was higher than 6 .

\section{Field Experiment}

At the beginning of the field experiment in 1973, after the enrichment of the soils with BNT, $\mathrm{pH} \mathrm{H}_{2} \mathrm{O}$ of the soils in the upper $30 \mathrm{~cm}$ layer was as follows: $6.5,8,0$, 8.3 , and 8.4 for the control soil, and soils with 30, 60, and $120 \mathrm{t} \mathrm{BNT} \mathrm{ha}^{-1}$, respectively. In 1976, which was the last year of this experiment, $\mathrm{pH} \mathrm{H}_{2} \mathrm{O}$ of the soils in the upper $30 \mathrm{~cm}$ layer changed to $6.1,6.7,7.1$, and 7.9 , respectively, for the control soil, $30 \mathrm{t} \mathrm{ha}^{-1} \mathrm{BNT}$, $60 \mathrm{t} \mathrm{ha}^{-1} \mathrm{BNT}$, and $120 \mathrm{tha}^{-1} \mathrm{BNT}$. The $\mathrm{pH}$ values in 1976 were correlated with the doses of BNT ( $r=0.995$, significant at $P=0.01, n=4)$.

Prior to establishing the field experiment, bacteria of the genus Azotobacter were found sporadically only in the limed soil. At the end of the field experiment, CFU numbers of these bacteria were as follows: 10, 317, 795, and 8,915 in $1 \mathrm{~g}$ of dry soils, in the control soil, and the soils with 30,60 , and $120 \mathrm{t} \mathrm{ha}^{-1}$ of BNT added, respectively. Most probably these bacteria were $A$. chroococcum, because they all turned dark brown after several days of incubation (Martyniuk and Martyniuk, 2003). The CFU numbers of these bacteria, converted to logarithms to base 10, were both correlated with BNT doses and the soil $\mathrm{pH}$ in 1976 ( $r=0.956$ and 0.980 , respectively, both significant at $P=0.05, n=4)$.

\section{Discussion}

As previously written [10-12], the enrichment of the basic soil (which was very poor in mineral colloids and organic matter) with BNT and organic and mineral fertilizers improved some physical (e.g., the increase of water-holding capacity) and some chemical (e.g., the increase of $\mathrm{pH}$ and contents of organic $\mathrm{C}$ and total $\mathrm{N}$ ) properties. The exposure of these soils during a further eight years to drastic conditions of bare fallowing without fertilization (when all labile substances were removed from the upper soil layer by decomposition by soil microorganisms or leaching by showers), allowed finding out that highly persistent organic-mineral complexes were formed in the upper layer of BNT-amended soils (especially of the soil with the highest dose of BNT). This phenomenon prevented the fine soil particle fraction from migrating into deeper soil layers. Therefore, the upper 30 $\mathrm{cm}$ layer of the soil was not depleted to a great extent of soil particles responsible for retention of water, organic matter, and various nutrients.

BNT contained substantial amounts of forms of $\mathrm{Mg}$, $\mathrm{Na}, \mathrm{K}$, and especially $\mathrm{Ca}$ that are soluble in $10 \% \mathrm{HCl}$, which were readily dissolvable minerals, including carbonates as well as these elements bound in the interlayer space or the surface of montmorillonite. Therefore, the enrichment of the sandy soil with BNT (especially with its higher dose) significantly reduced the acidification of the soil during both periods of plant cultivation and after longterm fallowing. However, these base substances, soluble in $10 \% \mathrm{HCl}$, gradually disappeared from the upper $30 \mathrm{~cm}$ soil layer during the experiment term, especially during the $7 / 8$-year bare fallowing [10-11].

After the inoculation of the soils with A. chroococcum in 1973, the highest CFU number of $A$. chroococcum was found in the control soil, and the lowest in the soil with $120 \mathrm{tha}^{-1}$. The sorption of these bacteria by BNT was probably the reason for the observed phenomenon. Theng and Orchard [29] reported that the sorption of bacteria by soils increases with clay content.

During 1974-1985, the $\mathrm{pH}$ changes were most probably the main cause of the changes in A. chroococcum's CFU numbers in the soils amended with BNT. In the BNT soils, the year means of $\mathrm{pH}$ were very significantly correlated with the means of CFU numbers of $A$. chroococcum.

As the $\mathrm{pH}$ of the control soil did not present the same pattern as that of BNT soils, and due to the fact that in the control soil the gradual decrease of $\mathrm{pH}$ was not observed due to occasional liming, the $\mathrm{pH}$ changes of the control soil were probably not the only reason for the gradual decrease of the CFU numbers of $A$. chroococcum in this soil. Only the decrease of $\mathrm{pH}$ to 5.8 in 1974 could be the main cause of the 5-fold decrease of the CFU numbers of $A$. chroococcum at that time in the control soil. In this year, $\mathrm{pH}$ of the BNT soils was much higher (it ranged from 7.2 to 7.8), and 2-5-fold increases of the CFU numbers of $A$. chroococcum were found in these soils. The other significant decreases of the CFU numbers of these bacteria in the control soil (6-fold in 1975, 15-fold in 1976, and 5-fold in 1979) happened when $\mathrm{pH}$ was not low $(6.7,6.8$, and 6.8).

Therefore, it cannot be excluded that other beneficial influences of BNT on these bacteria occurred, especially 
that at the same $\mathrm{pH}$ around 6.6-7.0, the numbers of $A$. chroococcum $\mathrm{CFU}$ in the BNT soils were approximately 10-20-times higher than those in the control soil. As pointed out by several authors, the enrichment of various sandy soils with bentonite increases their porosity and alters pore-size distribution by increasing the proportion of small pores [7-8, 30-31]. Therefore, bentonite is responsible for the creation of protective micro-habitats for bacteria (soil pores $<6 \mu \mathrm{m}$ ) against predation by protozoa [32-33]. Furthermore, van Elsas and Heijnen [34] reported that bentonite clay, which has the potential to serve as a carrier for introducing bacteria into soil, prolonged the survival of the introduced bacterial strain and promoted the occurrence of plasmid transfer at higher frequencies.

Significantly higher contents of organic carbon, total nitrogen, total manganese, available phosphorus, and water in the soils amended with BNT, especially with its highest dose [10-12], could also positively affect Azotobacter's CFU number in those soils. As was presented in several papers, the CFU number of Azotobacter in soils was positively correlated with organic $\mathrm{C}$ concentration [13-14, 26, 35-37], total $\mathrm{N}$ concentration [13-14, 37], total Mn concentration [38], and available phosphorus concentration [38-39]. Furthermore, Barnes et al. [35] found a positive relationship between the number of Azotobacter's CFU and soil water content, and Natywa et al. [40] discovered that field irrigation increased Azotobacter's CFU number in the soil.

Metabolic activity of these bacteria in the soil could also be positively affected by BNT addition. Heijnen et al. [41] reported that the presence of bentonite clay in loamy sand stimulated the metabolic activity of introduced rhizobia. Organic $\mathrm{C}$ was used more efficiently during growth in the bentonite-amended soil than in the unamended one.

Phiromtan et al. [42], studying the effect of various organic carriers on survival of Azotobacter vinelandii inoculum during its storage, emphasized that adding clay mineral to the carriers was a beneficial technique for improving the quality of the bioinoculant. This clay mineral component played a critical function in promoting physical and biochemical environments for this microbial population. The increase in high specific surface area of the carrier could promote adsorption of organic and inorganic substances, cation exchange capacity, and water-holding capacity, as well as encouraging microbial catabolism by increasing adherence and tolerance capacity of Azotobacter under hot conditions [42].

The CFU number of Azotobacter spp. (most probably A. chroococcum) at the end of the four-year field experiment was also positively correlated with $\mathrm{pH}$ of the soils. It is very interesting that BNT addition to this soil increased the CFU number of these bacteria by 30-900 times - amounts that seldom occur in agricultural soils [13-14, 40]. However, the lack of longer duration of this field experiment failed to show how persistent this increase would be. The highest values of CFU numbers of the native Azotobacter $\mathrm{spp}$. in this soil were recorded when soil $\mathrm{pH} \mathrm{H}_{2} \mathrm{O}$ was (similar to the microplot experiment) close to 8 . This is consistent with the data of Lenart [13] and Chenappa et al. [43], who found that $A$. chroococcum was the most numerous in slightly alkaline soils $\left(\mathrm{pH} \mathrm{H}_{2} \mathrm{O}\right.$ between 8 and 9). In the last two years of the plot experiment, after $7 / 8$ years of fallowing (and when $\mathrm{pH}$ of the upper soil layers significantly decreased), A. chroococcum was found only in the lower layer of the soil with the highest dose of BNT, where soil $\mathrm{pH} \mathrm{H}_{2} \mathrm{O}$ was higher than 6 , which is consistent with the results of Martyniuk and Martyniuk [14], who did not find A. chroococcum in soil with $\mathrm{pH}_{2} \mathrm{O}$ lower than 6.5 .

\section{Conclusions}

The addition of BNT (the waste bentonite containing carbonates) to a subsoil of a very poor acidic sandy soil significantly slowed the gradual decrease of the CFU number of Azotobacter chroococcum, introduced into the soil at the beginning of a 38-year-microplot experiment. Furthermore, BNT added to another sandy soil in a 4-yearfield experiment greatly increased the CFU number of native bacteria of genus Azotobacter, occurring in this soil in trace amounts prior to establishing the experiment. The effect of BNT on the CFU number of these bacteria was dose-dependent in both experiments. The increase of the soil $\mathrm{pH}$ by BNT addition was the main mechanism of the observed phenomenon.

\section{Acknowledgements}

The results of the study were scientifically described within the frames of Task 1.4. Evaluation and formation of biodiversity of soil and microbial activity of soil with regard to habitat conditions and management system. Multi - Annual Programme IUNG - PIB 2016-2020.

\section{References}

1. CROKER J., POSS R., HARTMANN C., BHUTHORNDHARAJ S. Effects of recycled bentonite addition on soil properties, plant growth and nutrient uptake in a tropical sandy soil. Plant Soil. 267, 155, 2004.

2. FILIPEK T. Natural and anthropogenic causes and effects of soil acidification. Fertilizers Fertilization. 3, 5, 2001.

3. FOTYMA M. PIETRUCH C. The actual status of soil reaction and demand for limestone in Poland. Fertilizers Fertilization. 3, 27, 2001.

4. KÁTAI J., TÁLLAI M., SÁNDOR Z., OLÁH ZSUPOSNÉ Á. Effect of bentonite and zeolite on some characteristics of acidic sandy soil and on the biomass of a test plant. Agrochem. Soil Sci. 59, 165, 2010.

5. NOBLE A.D., GILLMAN G.P., RUAYSOONGNERN S. A cation exchange index for assessing degradation of acid soil by further acidification under permanent agriculture in the tropics. Eur. J. Soil Sci. 51, 233, 2000.

6. LAZÁNYI J. Effects of bentonite on the water budget of sandy soil. In: Culture Technology for Wheat and Corn. 
Symp. Int., July 7-8, Oradea, University of Oradea Press, Romania. 293-300, 2005.

7. LHOTSKÝ J., KREMER J., PODLEŠÁKOVÁ E., SHRBENÁ B., SKOKAN E., SKOKANOVÁ P. Theory of bentonite behaviour in soils. Scientific monographs. Res. Institute for Land Reclamation and Improvement Press, Zbraslav, Czech Republic. 377, 1970.

8. SATJE A., NELSON P. Bentonite treatments can improve the nutrient and water holding capacity of sugarcane soils in the wet tropics. Proc. Australian Soc. Sugar Cane Technol. 31, 166, 2009.

9. YSSAD H.R., BELKHODJA M. The effect of bentonite on the physic chemical characteristics of sandy soils in Algeria. J. Applied Sci. 7, 2641, 2007.

10. CZABAN J., SIEBIELEC G. Effects of bentonite on sandy soil chemistry in a long-term plot experiment (II); Effect on $\mathrm{pH}, \mathrm{CEC}$, and macro- and micronutrients. Pol. J. Environ. Stud. 22, 1669, 2013.

11. CZABAN J., SIEBIELEC G., CZYŻ E., NIEDŹWIECKI J. Effects of bentonite on sandy soil chemistry in a longterm plot experiment (I); Effect on organic carbon and total nitrogen. Pol. J. Environ. Stud. 22, 1661, 2013.

12. CZABAN J., CZYŻ E., SIEBIELEC G., NIEDŹWIECKI J. Long-lasting effects of bentonite on properties of a sandy soil deprived of the humus layer. Int. Agrophys. 28, $1,2014$.

13. LENART A. Occurrence, characteristics, and genetic diversity of Azotobacter chroococcum in various soils of southern Poland. Pol. J. Environ. Stud. 21, 415, 2012.

14. MARTYNIUK S., MARTYNIUK M. Occurrence of Azotobacter spp. in some Polish soils. Pol. J. Environ. Stud. 3, 371, 2003.

15. RUBIO E.J., MONTECCHIA M.S., TOSI M., CASSAN F.D., PERTICARI A., CORREA O.S. Genotypic characterization of azotobacteria isolated from Argentinean soils and plant-growth-promoting traits of selected strains with prospects for biofertilizer production. Sci. World J., Soil Science, Article ID 519603. 12, 2013.

16. YAO H.-Q. Biological nitrogen fixation. In: Zhu Z.-L. et al. (eds.) Nitrogen in Soils of China. Kluwer Academic Publishers, Springer Science+Business Media Dordrecht, B.V. 135, 1997.

17. ABDEL-AZIEZ S.M., EWEDA W.E., GIRGIS M.G.Z., ABDEL GHANY B.F. Improving the productivity and quality of black cumin (Nigella sativa) by using Azotobacter as $\mathrm{N}_{2}$ biofertilizer. Ann. Agric. Sci. 59, 95, 2014.

18. AQUILANTI L., FAVILLI F., CLEMENTI F. Comparison of different strategies for isolation and preliminary identification of Azotobacter from soil samples. Soil Biol. Biochem. 36: 1475, 2004.

19. BARAL B.R., ADHIKARI P. Effect of Azotobacter on growth and yield of maize. SAARC J. Agri. 11, 141, 2013.

20. ELGALA A.M., ISHAC Y.Z., ABDEL MONEM M., EL-GHANDOUR I.A.I. Effect of single and combined inoculation with Azotobacter and VA mycorrhizal fungi on growth and mineral nutrient contents of maize and wheat plants. In: Huang, P. M. et al. (eds.) Environmental Impact of Soil Component Interactions. Metals, Other Inorganics, and Microbial Activities. Volume II, Lewis Publishers, Boca Raton, London, Tokyo. 109, 1995.

21. GAURI S.S., MANDAL S.M., PATI B.R. Impact of Azotobacter exopolysaccharides on sustainable agriculture. Appl. Microbiol. Biotechnol. 95, 331, 2012.

22. JNAWALI A.D., OJHA R.B., MARAHATTA S. Role of Azotobacter in soil fertility and sustainability - A review. Adv. Plants Agric. Res. 2, 1, 2015.
23. KIZILKAYA R. Yield response and nitrogen concentrations of spring wheat (Triticum aestivum) inoculated with Azotobacter chroococcum strains. Ecol. Engin. 33, 150, 2008.

24. MIRIM.R., MOGHADAMH.R.T., GHOOSHCHI, ZAHEDI H. Effect of Azotobacter and arbuscular mycorrhizal colonization enhance wheat growth and physiological traits under well-watered and drought conditions. Adv. Environ. Biol. 7, 4630, 2013.

25. WANI S.A., CHAND S., ALI T. Potential use of Azotobacter chroococcum in crop production: An overview. Curr. Agric. Res. J. 1, 35, 2013.

26. CHANNAL H.T., ALAGAWADI A.R., BHARAMAGOUDAR T.D., UDUPA S.G., PATIL P.D., MANNIKERI I.M. Azotobacter population as influenced by soil properties in some soils of north Karnataka. Curr. Sci. 58, 70, 1989.

27. KIZILKAYA R. Nitrogen fixation of Azotobacter spp. strains isolated from soils in different ecosystems and relationship between them and the microbiological properties of soils. J. Environ. Biol. 30, 73, 2009.

28. BURK D. The influence of nitrogen gas upon the organic catalysis of nitrogen fixing by Azotobacter. J. Phys. Chem. 34, 1174, 1930.

29. THENG B.K.G., ORCHARD V.A. Interactions of clays with microorganisms and bacterial survival in soil: A physicochemical perspective. In: Huang, P. M. et al. (eds.) Environmental Impact of Soil Component Interactions. Metals, Other Inorganics, and Microbial Activities. Volume II, Lewis Publishers, Boca Raton, London, Tokyo. 123, 1995.

30. HEIJNEN C.E., CHENU C., ROBERT M. Micromorphological studies on clay amended and unamended loamy sand, relating survival of introduced bacteria and soil structure. Geoderma. 56, 195, 1993.

31. SUZUKI S., NOBLE A.D., RUAYSOONGNERN S., CHINABUT N. Improvement in water-holding capacity and structural stability of a sandy soil in northeast Thailand. Arid Land Res. Manag. 21, 37, 2007.

32. HEYNEN C.E., VAN ELSAS J.D., KUIKMAN P.J., VAN VEEN J.A. Dynamics of Rhizobium leguminosarum biovar trifolii introduced into soil; the effect of bentonite clay on predation by protozoa. Soil Biol. Biochem. 20, 483, 1988.

33. HEIJNEN C.E., HOK-A-HIN C.H., VAN VEEN J.A. Improvements to the use of bentonite clay as a protective agent, increasing survival levels of bacteria introduced into soil. Soil Biol. Biochem. 24, 533, 1992.

34. VAN ELSAS J.D., HEIJNEN C.E. Methods for the introduction of bacteria into soil: A review. Biol. Fertil. Soils. 10, 127, 1990.

35. BARNES R.J., BAXTER S.J., LARK R.M. Spatial covariation of Azotobacter abundance and soil properties: A case study using the wavelet transform. Soil Biol. Biochem. 39, $295,2007$.

36. STYŁA K., SAWICKA A. Microbiological activity of soil against the background of differentiated irrigation and fertilization in apple (Malus domestica) orchard after replantation. Agron. Res. 8, 827, 2010.

37. MAZINANI Z., AMINAFSHAR M., ASGHARZADEH A., CHAMANI M. Effect of Azotobacter population on physicochemical characteristics of some soil samples in Iran. Ann. Biol. Res. 3, 3120, 2012.

38. PISAREK I., GRATA K. The influence of the organic matter of sewage sediments on biological activity of microorganisms which carry out the transformations of carbon and nitrogen compouds. Pol. J. Microbiol. 62, 445, 2013. 
39. GANDOTRA V., GUPTA R.D., BHARDWAJ K.K.R. Abundance of Azotobacter in great soil groups of north-west Himalayas. J. Indian Soc. Soil Sci. 1998, 379, 1998.

40. NATYWA M., SELVET M., AMBROŻY K., POCIEJOWSKA M. The effect of nitrogen fertilization and irrigation on the number of Azotobacter in the soil under maize at different stages of plant development. Pol. J. Agron. 14, 53, 2013.

41. HEIJNEN C.E., BURGERS S.L.G.E., VAN VEEN J.A. Metabolic activity and population dynamics of rhizobia introduced into unamended and bentonite-amended loamy sand. Appl. Environ. Microbiol. 59, 743, 1993.
42. PHIROMTAN M., MALA T., SRINIVES P. Effect of various carriers and storage temperatures on survival of Azotobacter vinelandii NDD-CK-1 in powder inoculant. Mod. Appl. Sci. 7, 81, 2013.

43. CHENAPPA G., NAIK M.K., ADKAR-PURUSHOTHAMA C.R., AMARESH Y.S., SREENIVASA M.Y. PGP potential, abiotic stress tolerance and antifungal activity of Azotobacter strains isolated from paddy soils. Indian J. Exp. Biol. 54, 322, 2016. 